\title{
1. INTRODUCTION: LEG 163 BACKGROUND AND OBJECTIVES ${ }^{1}$
}

\author{
H.C. Larsen ${ }^{2}$ and R.A. Duncan ${ }^{3}$
}

Ocean Drilling Program (ODP) Leg 163 is the second of two drilling legs to the Southeast Greenland margin. Together with Leg 152 (Larsen, Saunders, Clift, et al., 1994) this program addresses the nature of rifting and breakup at this rifted continental margin and in particular assesses the impact of the Iceland mantle plume on breakup and early seafloor spreading. These investigations build on earlier Deep Sea Drilling Project (DSDP) and ODP drilling (Leg 81-Roberts, Schnitker, et al., 1984; Leg 104 -Eldholm, Thiede, Taylor, et al., 1989) and form part of a larger geological and geophysical margin study (Larsen, 1995).

The strategy for drilling and the detailed background and objectives have been outlined by Larsen, Saunders, Clift, et al. (1994). In this introduction we only briefly summarize the main strategy and objectives, the geophysical database, and the most important findings of Leg 152 and their implications for the detailed planning of Leg 163.

\section{DRILLING AREA AND STRATEGY}

The Southeast Greenland margin is a type example of a volcanic rifted margin. The margin is characterized by a broad seaward-dipping reflector sequence (SDRS) that onlaps continental (mainly Precambrian) crust to the west and terminates eastward in oceanic crust of early Tertiary age (Figs. 1,2).

In the Northeast Atlantic, seafloor-spreading Anomalies $24 \mathrm{~N}-$ $24 \mathrm{R}$ are the oldest identified pair of anomalies (Talwani and Eldholm, 1977; Srivastava and Tapscott, 1986; Larsen, 1988). Anomaly $24 \mathrm{~N}$ is developed off Southeast Greenland as a doublepeaked anomaly (24A and 24B in Fig. 1) reflecting the three short positive events C24n.1 through C24n.3 (Cande and Kent, 1992) and the relatively high spreading rates during this interval (approximately $3 \mathrm{~cm} / \mathrm{yr}$ half-rate; Larsen, 1980).

The minimum age of the Southeast Greenland SDRS is constrained by the seaward occurrence of well-developed seafloorspreading anomalies (Fig. 1; Larsen and Jakobsdóttir, 1988). In the north, close to the Faeroe-Iceland-Greenland Ridge, the SDRS extends seaward to seafloor of Chron C22n-C21n age (49-47 Ma). However, most of the Southeast Greenland SDRS is found landward of seafloor spreading Anomaly $24 \mathrm{~A} / 24 \mathrm{~B}$ and thus is older than C24n.1 (53 Ma; Cande and Kent, 1992). Weak and semilinear magnetic anomalies present over the main SDRS may represent either

'Duncan, R.A., Larsen, H.C., Allan, J.F., et al., 1996. Proc, ODP, Init. Repts., 163: College Station, TX (Ocean Drilling Program).

${ }^{2}$ Danish Lithosphere Center, Øster Volgade 10, DK-1350 København, Denmark. larsenhc@dlc.ggu.min.dk

${ }^{3}$ College of Oceanic and Atmospheric Sciences, Oregon State University, Oceanog. raphy Administration Building 104, Corvallis, OR 97331-5503, U.S.A.

rduncan@oce.orst.edu low-amplitude anomalies older than C24n (e.g., C25n-C27n, 56-61 $\mathrm{Ma}$ ) or short magnetic events within C24r (the cryptochrons of Cande and Kent, 1992; see also discussion in "Summary" chapter, Larsen, Saunders, Clift, et al., 1994).

Evidence for significant magmatism and tectonism during breakup is not restricted to the offshore areas. A coast-parallel dike swarm and associated seaward flexuring of the crust are present from the Leg 163 EG66 transect northward. Within this zone are gabbroic and syenitic intrusions (Fig. 1; Myers, 1980; Myers et al., 1993) locally associated with basaltic lavas overlying thin sediments (for review see Larsen, 1980; Nielsen et al., 1981; Brooks and Nielsen, 1982). Farther north a much more extensive and thicker flood basalt province is preserved (Fig. 1; Larsen et al., 1989). Comprehensive studies of the onshore region are being conducted in parallel with ODP drilling and will be augmented in 1996 with a mainly marine program of deep crustal seismic imaging that includes the region of the ODP transects (Larsen, 1995; Larsen et al., 1995). In particular, ODP drilling and field geological studies will aim at correlating the on- and offshore parts of the crustal flexure zone and the volcanic stratigraphy within the two areas.

Drilling was positioned along two margin transects, located distal (Legs 152 and 163) and proximal (Leg 163) to the Iceland plume center (the track of which is recorded by the Faeroe-Iceland-Greenland Ridge). The respective transects were named EG63 and EG66, referring to their approximate latitude (Fig. 3). At each transect drilling was targeted at the prerift crust, the breakup unconformity and earliest volcanism, the transition from initial continental volcanism to ocean crust volcanism, and, most seaward, a reference hole in steadystate spreading crust. This drilling strategy was designed (Larsen et al., 1991) with two primary objectives: (1) investigation of the development with time along each transect will tell us about the progressive weakening of the continental crust and the associated magmatic development and (2) the study of magmatic development and the magma source at different offsets from the Iceland plume will enable us to evaluate possible radial zonation in the original plume structure. Additional reference points for the second objective are provided by earlier DSDP Leg 81 drilling at the Hatton Bank margin (most distal southern offset; Joron et al., 1984) and ODP Leg 104 drilling at the Vøring margin (intermediate northern offset; Viereck et al., 1988; see also Larsen, Saunders, Clift, et al., 1994).

\section{GEOPHYSICAL DATABASE}

Legs 152 and 163 are based on a large set of seismic data over the Southeast Greenland margin (Fig. 3). The database comprises three different sets of seismic data: (1) regional to detailed grids of shallow, high-resolution multichannel seismic (MCS) data (Larsen et al., 1994); (2) regional grid of deep 7-s two-way traveltime (TWT) MCS data; and (3) deep 14-s TWT MCS data (Larsen et al., 1995). In addition, aeromagnetic and regional marine gravity data exist (for more extensive review and references see Larsen, 1990; Larsen, Saunders, Clift, et al., 1994). 


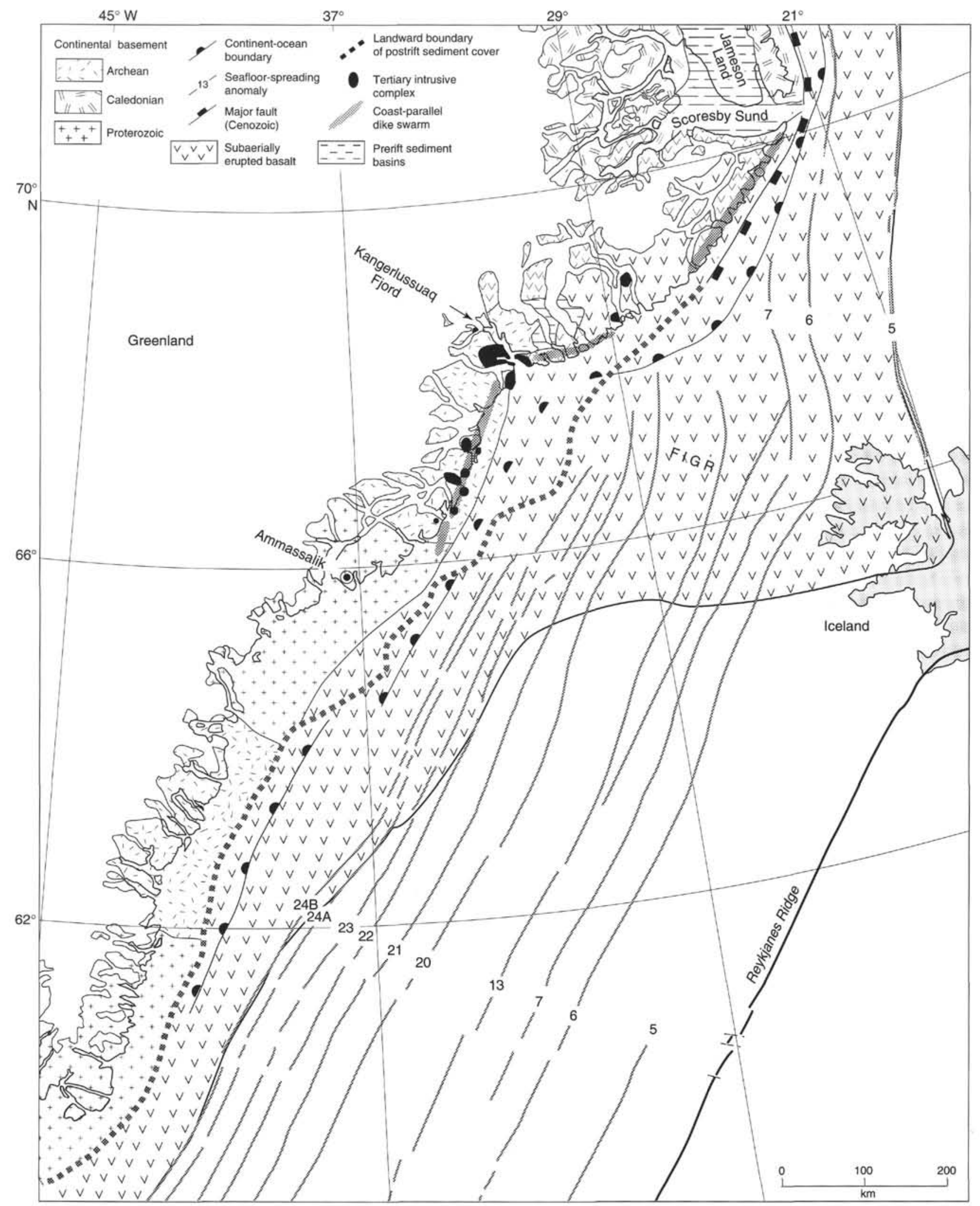

Figure 1. Geological map (modified from Larsen, 1990). The subaerially erupted basalts show flood basalt structure landward of the inferred continent-ocean boundary (COB) and SDRS structure seaward of the COB. The part of northwestern Iceland that shows SDRS-like structure is included. Note that the spreading history of the Iceland Plateau north of the Faeroe-Iceland-Greenland Ridge (FIGR) is different from that south of the ridge. In the young crust north of the FIGR, the typical SDRS structure is not continuously present and extends to a depth of only about $2 \mathrm{~km}$. However, below the ridge itself, the SDRS may attain a thickness of $10 \mathrm{~km}$ (Larsen and Jakobsdóttir, 1988). 

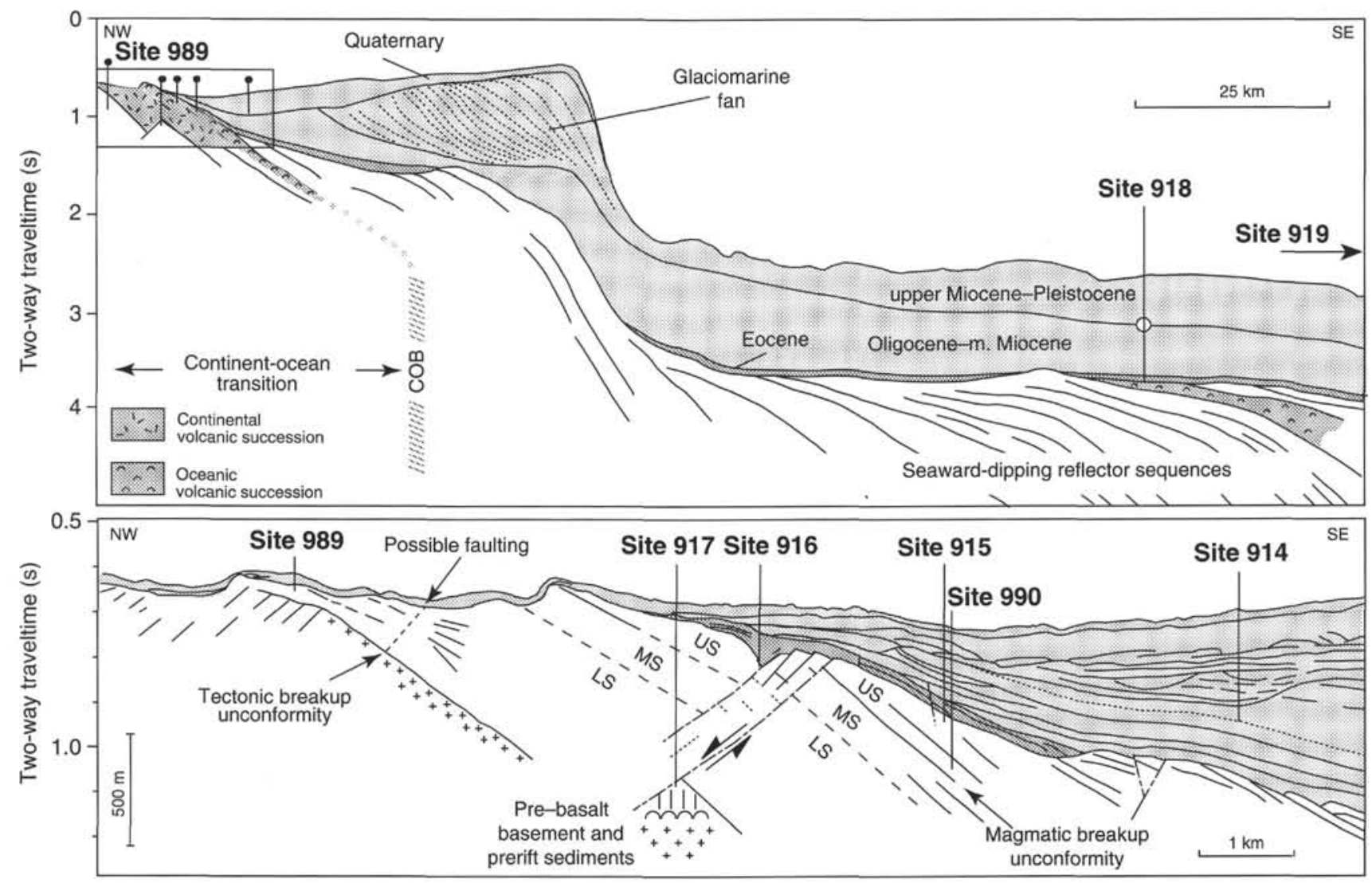

Figure 2. Interpreted cross section along the EG63 transect showing major units. Note that the tectonic breakup unconformity and the development from continental to oceanic volcanism are separated by a $\sim 1-\mathrm{km}$-thick, highly variable continental volcanic succession (picrites to dacites). Apart from an initial picritic sequence, the oceanic succession is believed to be quite uniform throughout the entire SDRS (depleted Iceland-type tholeiites). The inferred continent-ocean boundary $(\mathrm{COB})$ is shown at the estimated source region for the lower part of the oceanic succession. As shown on the enlarged section in the lower panel, the continental succession of lavas comprises the Lower (LS) and Middle Series (MS), and the oceanic succession of lavas comprises the Upper Series (US) and younger lavas throughout the SDRS.

\section{LEG 152 RESULTS AND IMPLICATIONS FOR LEG 163}

A number of important observations made during Leg 152 drilling into the Southeast Greenland SDRS significantly affected the detailed planning of Leg 163 (Fig. 2): (1) highly tilted to subvertical prerift sediments occur below the inner part of the SDRS; (2) an ear$\mathrm{ly}$, continentally hosted and contaminated basaltic to andesitic volcanism of 61-62 Ma age (Sinton et al., 1994) overlies these sediments; (3) the upper limit of these lower lavas is a sharp transition-possibly a hiatus - into picritic to tholeiitic lavas followed by basalts of a rather uniform composition that resemble depleted tholeiites from Iceland and appear to make up the main part of the SDRS; and (4) all recovered igneous units were erupted subaerially. Thus, Leg 152 confirmed that the SDRS is a wedge of predominantly basaltic material extruded subaerially in accord with the model for crustal accretion in Iceland (Pálmason, 1986) and with the interpretation of seismic data (Mutter et al., 1982; Larsen and Jakobsdóttir, 1988).

The Leg 152 findings imply that the transition from continental to oceanic crust takes place below the inner part of the SDRS. During formation of this continent to ocean transition, prerift sediments were deposited in a basin of unknown width and later in a zone close to the final line of breakup, and they were subjected to faulting, uplift, and erosion prior to volcanism (see also Larsen, Saunders, Clift, et al., 1994).
The Leg 152 data are deficient in a number of aspects. These include a lack of suitable material for age determination of the oceanic succession (i.e., the main part of the SDRS), noncontinuous sampling of the transition from initial picritic to depleted tholeiitic volcanism within the oceanic succession, and nonrecovery of the oldest part of the continental succession (Fig. 2). In addition, the prerift sediments were poorly sampled because of their subvertical orientation (i.e., essentially bed-parallel coring), and they have been too strongly metamorphosed to yield any age-diagnostic fossils or palynomorphs.

Leg 163 was planned to overcome these deficiencies within the southern EG63 transect, as well as to sample the breakup and early seafloor-spreading volcanism in a more proximal position to the proposed Iceland hotspot track, along the northern EG66 transect. The faint signature of the Iceland plume in the Leg 152 rocks suggests that a stronger plume imprint could be present at this location closer to the former plume axis, which, if true, would indicate a radial zonation within the original plume structure.

Integration of observations from drilling, field geology, and geophysics on crustal structure and deformation, timing of volcanism, and the involvement of Iceland plume material in the breakup process eventually will enable a critical review of current models of plume structure and the impact of mantle plumes on the process of continental breakup (e.g., Mutter et al., 1988; White and McKenzie, 1989; Richards et al., 1989; Campbell and Griffiths, 1990; Coffin and Eldholm, 1992; Kent et al., 1992; Holbrook and Keleman, 1993). 


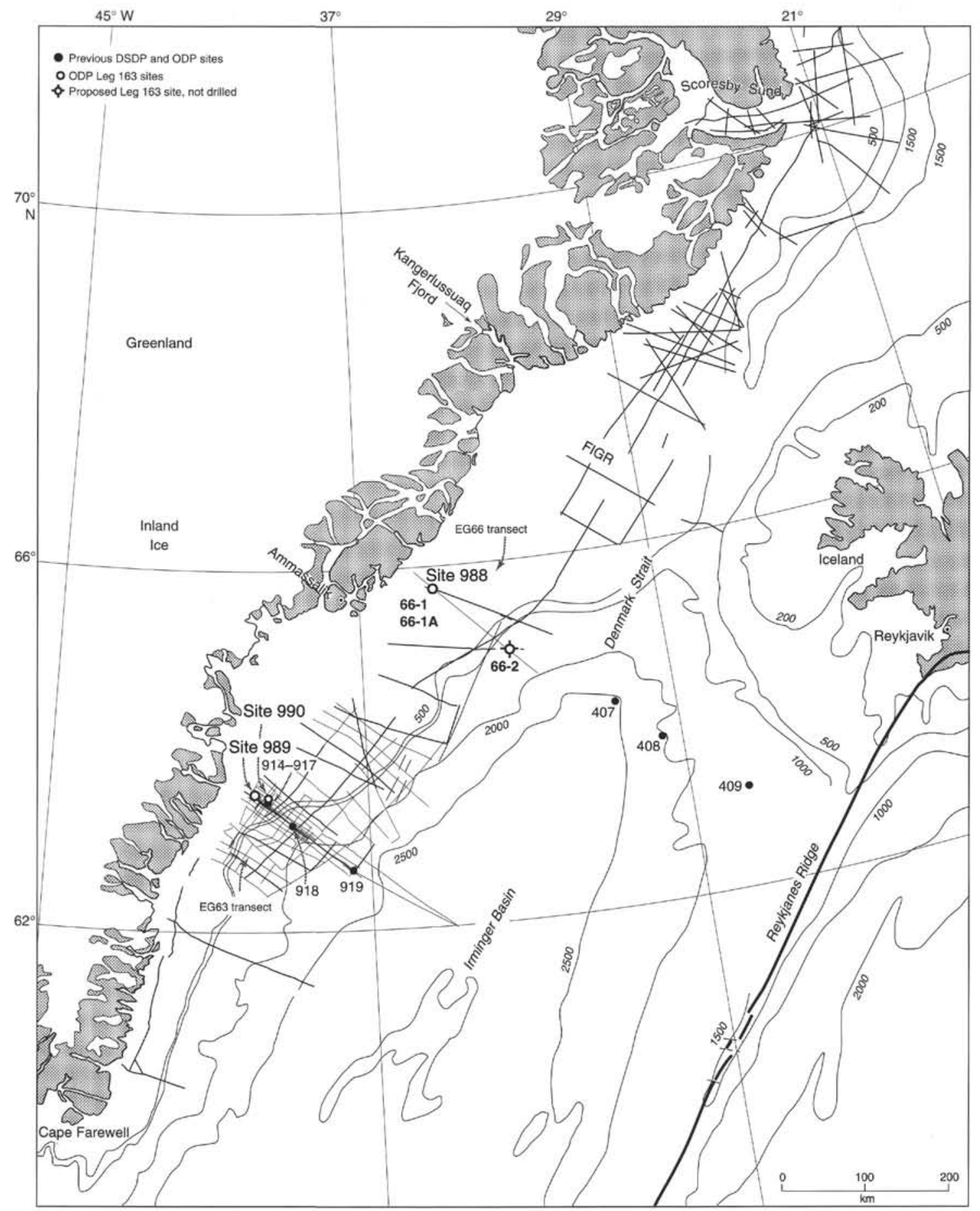

Figure 3. Seismic track map and regional bathymetry. Leg 163 proposed and drilled sites and other DSDP/ODP sites are shown.

\section{DRILLING PLAN}

To meet the main objectives, a total of six first-priority sites was planned for the two transects. Three sites were planned for the innermost part of the EG63 transect. Two of these were targeted to increase the sampling of the prerift crust and oldest volcanic cover and one site was to deepen Site 915 in order to provide stratigraphic overlap with Site 917 (Figs. 2, 4).
Three sites were also planned for the northern EG66 transect (Fig. 5). The two sites within the innermost part of this transect have objectives roughly similar to the inner sites of the EG63 transect, though less ambitious in terms of stratigraphic coverage. The additional seaward site was planned in SDRS-type oceanic crust of Anomaly 22 age (i.e., in steady-state accreting Icelandic-type oceanic crust). The goal of this site is twofold: (1) to sample oceanic volcanism within the SDRS uncontaminated by continental crust and (2) to investigate 
any increased (or decreased) presence of a plume component with time along the EG66 transect.

\section{CHANGES IN THE DRILLING PLAN IMPOSED BY DRILLING PROBLEMS AND WEATHER}

A drilling accident and damage to the ship sustained during extreme storm conditions reduced the scientific drilling operations during Leg 163 to less than one-half of the planned program.

Recoil from a break in the drill pipe on 10 September 1995 damaged the top drive assembly after only one day of drilling at the first, shallow-water site (see "Operations" section, "Site 988" chapter, this volume). A port call to Reykjavik, Iceland, was made for the necessary repairs. Permission to drill in water depths shallower than $300 \mathrm{~m}$ (proposed Sites EG66-1 and EG66-1A; Figs. 3, 5) was temporarily withdrawn by ODP, pending review of safety procedures and delivery of supplementary drilling hardware. Operations therefore resumed at the deeper water sites along the southern EG63 transect on 16 September. Drilling progressed, though with interruptions because of heavy seas and icebergs drifting across the drill sites, until 29 September.

Extreme hurricane conditions built rapidly through the night of 29 September to the following morning (see "Operations" section, "Site 990 " chapter, this volume). At times the north-northeast wind exceeded $100 \mathrm{kt}$, and it remained at hurricane force for at least $12 \mathrm{hr}$. By the morning of 30 September the ship was being battered by shortperiod, 60-70-ft-high waves and was unable to maintain position without risking severe damage. The ship's bridge took water through a broken window, which caused both radars to fail and threatened to flood the computers of the dynamic-positioning system. Several thrusters were mechanically damaged or became inoperable because of flooding. In spite of reduced maneuverability the ship was able to maintain heading in the wind and sea while it was being forced south at a speed of up to $4 \mathrm{kt}$. While drifting in this manner, there was an increased potential of colliding with icebergs. When the storm abated to gale force on 1 October, the ship was turned to the south and the transit to Halifax, Nova Scotia, for repair was started.

At this point, the two co-chief scientists were informed that a thorough examination of the ship's structure and systems was needed after this calamity. This eliminated Reykjavik as a destination for temporary repair and thereby ruled out the possibility of further drilling operations during Leg 163. As a result of these force majeure events, only three of the planned six sites were drilled.

\section{PRINCIPAL RESULTS OF LEG 163 DRILLING}

In the following site chapters, results from each of the sites drilled during Leg 163 are presented by the shipboard scientific party. Despite the significant loss of operational time resulting from environmental conditions, the extraordinary recovery of core at three critical sites will provide the material to address several of the high-priority objectives of the leg. However, the main tectonic objective of drilling through the breakup unconformity and sampling the prerift crust, presumably sediments, was not fulfilled.

Our major conclusions, based on Leg 163 shipboard studies in the context of the Leg 152 results, are as follows:

1. There now exists a comprehensive record of the volcanic evolution of the East Greenland margin at latitude $63^{\circ} \mathrm{N}$, from the earliest, continentally contaminated, relatively deeply segregated magmas, through breakup-related picritic and tholeiitic magmas derived by shallower and larger degrees of melting, to a steady-state oceanic magma series.

2. Preliminary identification of two magnetic normal polarity intervals, the first ever recorded from the early Tertiary age volcanic rocks of East Greenland, and the recovery of fresh, feldspar-phyric flow units suitable for radiometric dating offer the promise of a detailed and precise time scale for the volcanic activity. This basic chronology will reveal the timing and rates of volcanic and tectonic processes.

3. The Iceland plume mantle component apparently is more strongly expressed in the composition of the igneous unit drilled at latitude $66^{\circ} \mathrm{N}$ compared with the lavas within the EG63 transect. Together with evidence from Leg 81 (Hatton Bank), Leg 104 (Vøring Plateau), and land exposures, we now have regional information that will enable us to map the basic compositional structure of the mantle melting regime that existed within the Iceland plume during the breakup of the North Atlantic.

The geochemical stratigraphy along the EG63 transect is shown in Figures 2 and 6. Drilling at Site 989 recovered lavas located immediately over the breakup unconformity. According to the seismic interpretation of the structure along the transect (Fig. 2), these should be located stratigraphically below the Lower and Middle Series drilled at Site 917. However, some normal faulting, possibly involving a strike-slip component, is interpreted to have occurred between Site 989 and Site 917 (Fig. 7). Another uncertainty in the correlation between Site 917 and Site 989 is the possibility that if drilling at Site 917 is through the normal fault seaward of the top of the fault block rather than right on top of it, recovery at Site 917 should include some of the earliest lavas above the breakup unconformity. However, the geochemical nature of the Site 989 lavas, in particular their $\mathrm{Ba}$ and $\mathrm{Sr}$ contents, is distinct from that of the Lower and Middle Series. Also, the minimum 65-m-thick flow Unit 1 at Site 989, a compound flow, is thicker than any lavas recovered at Site 917 and according to the shipboard measurements it carries a clear normal polarity magnetization, unlike the entirely reversely magnetized lavas of Site 917 . We therefore conclude that the Site 989 lavas, and the stage of volcanic development they represent within the process of breakup, are not represented in the Site 917 lavas.

In many ways, the Site 989 lavas compare more closely to the later, Iceland-type tholeiitic (oceanic) part of the volcanism found at Sites $915 / 990$ and 918 (Fig. 8). This surprising observation can be interpreted in two ways: (1) initial volcanism was not contaminated by continental crust (at least not by the same type of crust as seen in the Site 917 lavas) or (2) the Site 989 lavas represent a younger, off-axis event (i.e., younger than the Lower and Middle Series). The latter interpretation seems extremely difficult to reconcile with the seismic information and would imply that the entire Site 917 volcanic sequence is missing at Site 989 and the stratigraphic level of Sites $915 / 990$ is located directly on the rift unconformity at Site 989 . With only about $5 \mathrm{~km}$ between Sites 989 and 917, this seems unlikely.

Important questions to be addressed by shore-based studies are the age and isotopic composition of the Site 989 lavas to determine whether they could represent melted continental lithospheric mantle (e.g., Hawkesworth et al., 1990; Hergt et al., 1991) that formed during early breakup or whether they are related to younger, more oceanic volcanism.

The recovery of two normally magnetized zones (Fig. 6) within the featheredge of the SDRS will help considerably in determining the precise timing of the onset of volcanism and the absolute timing of the different stages in the progressive thinning of the continental lithosphere and the onset of igneous crustal accretion (main SDRS) represented by the Sites $915 / 990$ stratigraphic level. 

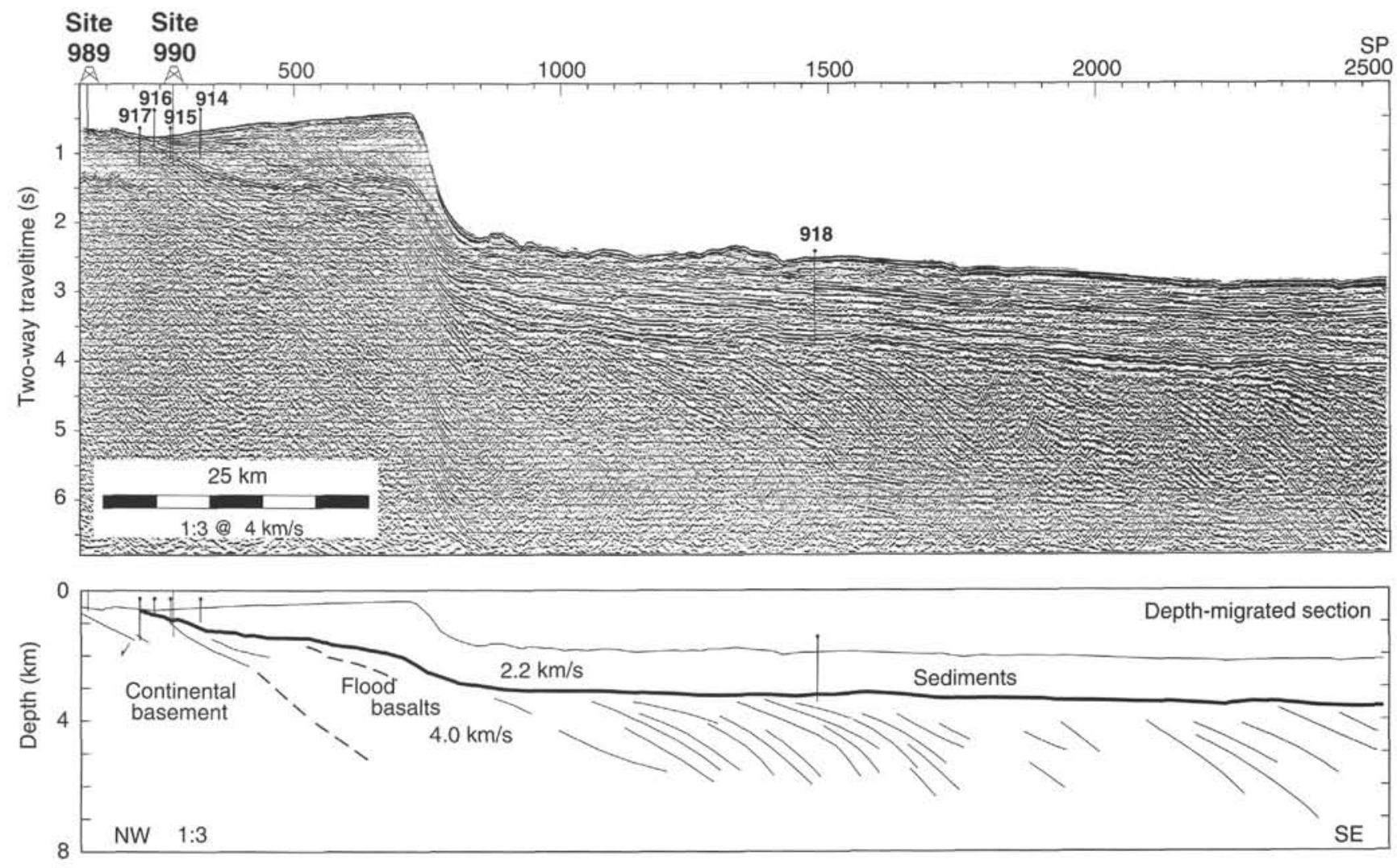

Figure 4. Regional seismic Line GGU81-08 and interpretation along the EG63 transect.
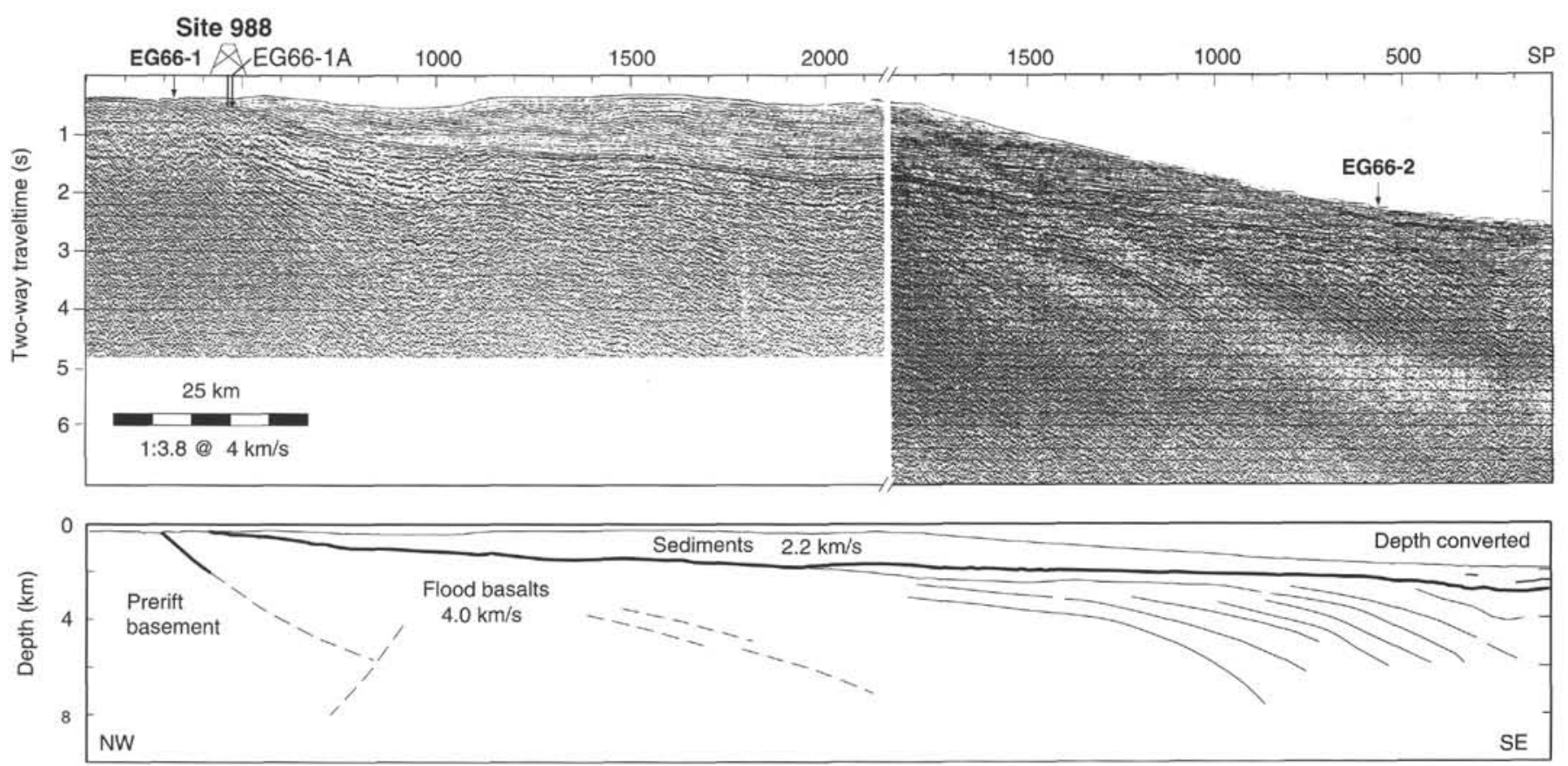

Figure 5. Spliced composite and interpretation of regional seismic Lines GGU82-01 and GGU82-02/2A along the EG66 transect. The line is spliced together (break in data) from the two regional lines through the inner and outer sites, respectively. 


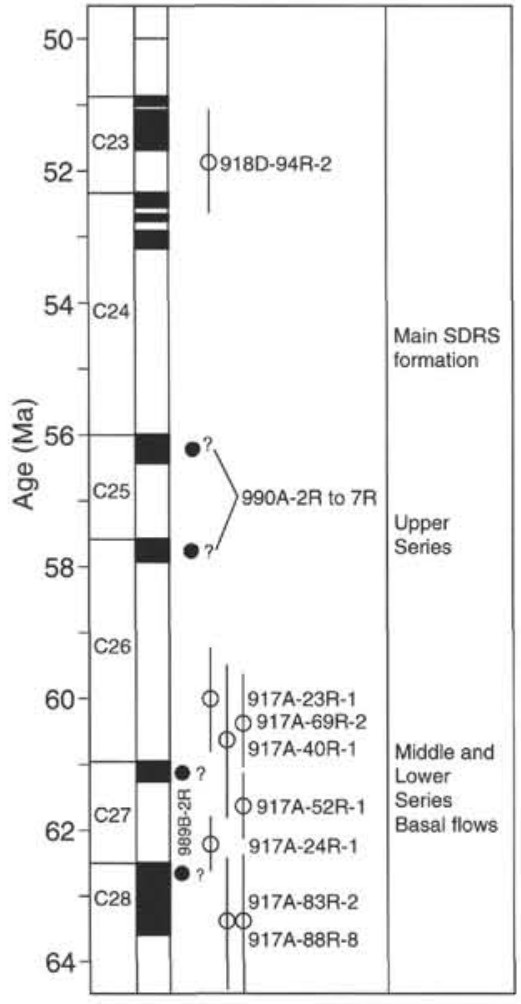

Figure 6. Magneto- and chronostratigraphy of the SDRS along the EG63 transect. Note that the Site 918 sample represents a younger sill or invasive flow and not the age of the main SDRS at the Site 918 location. The Site 918 SDRS lavas have been interpreted to be of magnetic Chron C24r age by combining biostratigraphic, chronostratigraphic, and magnetostratigraphic data (Ali and Vandamme, in press). The SDRS terminates seaward at approximately Chron C24n.2 time (Larsen and Jakobsdóttir, 1988).

A considerable enrichment in incompatible elements is seen in the Site 988 igneous units recovered from the northern EG66 transect, which is about $300 \mathrm{~km}$ closer to the Faeroe-Iceland-Greenland Ridge than the EG63 transect (Fig. 8). Though only two igneous units were sampled at Site 988, their compositional similarity to the roughly contemporaneous onshore Scoresby Sund basalts, younger Eastern Iceland basalts, and basalts from DSDP Site 407 (Table 4, "Site 988" chapter, this volume) is striking. The distance between Site 988 and the paleoposition of the Iceland plume, given by the intersection of the Faeroe-Iceland-Greenland Ridge with the East Greenland margin, is similar to that of Sites 407-409 from Iceland (Fig. 3). Iceland plume enrichment similar to that found at Site 988 and Sites 407-409 is demonstrated to be present at approximately the same distance away from Iceland along the Reykjanes Ridge (Schilling, 1986). This observation suggests that the generation of enriched, Iceland-type tholeiites has been limited to about the same $(\sim 200-300 \mathrm{~km})$ offset from the center of the Iceland hotspot since the inception of rifting and ocean floor formation.

However, Thirlwall (1995) and Thirlwall et al. (1994) recently found that Iceland plume material could be detected, on the basis of $\mathrm{Sr}-\mathrm{Nd}-\mathrm{Pb}$ isotopic compositions of basalts from the Reykjanes Ridge and from Northeast Greenland, to a much greater distance from Iceland than indicated by Schilling (1986). Moreover, Fram and Lesher (1993) and Kerr (1994) have pointed out the effect of lithospheric thickness on decompression melting and basalt compositions. Therefore, we recognize the limitations of the present shipboard data in assessing large-scale models of plume structures, which eventually will depend on a much larger data set including ongoing shore-based stud- ies of North Atlantic Igneous Province (NAIP) material and deep crustal studies (Larsen et al., 1995; Larsen et al., in press).

\section{REFERENCES}

Ali, J., and Vandamme, D., in press. Constraints of paleomagnetic data from basement rocks of Site 917 on the volcanic and tectonic history of East Greenland margin SDRS. In Saunders, A.D., Larsen, H.C., Clift, P.D., and Wise, S.W., Jr. (Eds.), Proc. ODP, Sci. Results, 152: College Station, TX (Ocean Drilling Program).

Brooks, C.K., and Nielsen, T.F.D., 1982. The East Greenland continental margin: a transition between oceanic and continental magmatism. $J$. Geol. Soc. London, 139:265-275.

Campbell, I.H., and Griffiths, R.W., 1990. Implications of mantle plume structure for the evolution of flood basalts. Earth Planet. Sci. Lett., 99:79-93.

Cande, S.C., and Kent, D.V., 1992. A new geomagnetic polarity time scale for the Late Cretaceous and Cenozoic. J. Geophys. Res., 97:1391713951.

Coffin, M.F., and Eldholm, O., 1992. Volcanism and continental break-up: a global complication of large igneous provinces. In Storey, B.C., Alabaster, T., and Pankhurst, R.J. (Ed.), Magmatism and the Causes of Continental Break-up. Geol. Soc. Spec. Publ. London, 68:17-30.

Eldholm, O., Thiede, J., Taylor, E., et al., 1989. Proc. ODP, Sci. Results, 104: College Station, TX (Ocean Drilling Program).

Fram, M.S., and Lesher, C.E., 1993. Geochemical constraints on mantle melting during creation of the North Atlantic basin. Nature, 363:712715 .

Hawkesworth, C.J., Kempton, P.D., Rogers, N.W., Ellam, R.M., and van Calsteren, P.W., 1990. Continental mantle lithosphere, and shallow level enrichment processes in the Earth's mantle. Earth Planet. Sci. Lett., 96:256-268.

Hergt, J.M., Peate, D.W., and Hawkesworth, C.J., 1991. The petrogenesis of Mesozoic Gondwana low-Ti: flood basalts. Earth Planet. Sci. Lett., 105:134-148.

Holbrook, W.S., and Keleman, P.B., 1993. Large igneous province on the US Atlantic margin and implications for magmatism during continental breakup. Nature, 364:433-436.

Joron, J.L., Bougault, H., Maury, R.C., Bohn, M., and Desprairies, A., 1984. Strongly depleted tholeiites from the Rockall Plateau margin, North Atlantic: geochemistry and mineralogy. In Roberts, D.G., Schnitker, D., et al., Init. Repts. DSDP, 81: Washington (U.S. Govt. Printing Office), 783-794.

Kent, R.W., Storey, M., and Saunders, A.D., 1992. Large igneous provinces: sites of plume impact or plume incubation? Geology, 20:891-894.

Kerr, A.C., 1994. Lithospheric thinning during the evolution of continental large igneous provinces: a case study from the North Atlantic Tertiary province. Geology, 22:1027-1030.

Larsen, H.C., 1980. Geological perspectives of the East Greenland continental margin. Bull. Geol. Soc. Den., 29:77-101.

, 1988. A multiple and propagating rift model for the Northeast Atlantic. In Morton, A.C., and Parson, L.M. (Eds.), Early Tertiary Volcanism and the Opening of the Northeast Atlantic. Geol. Soc. Spec. Publ. London, 39:157-158.

1990. The East Greenland Shelf. In Grantz, A., Johnson, G.L., and Sweeney, J.F. (Eds.), The Arctic Ocean Region: Boulder, CO (Geol. Soc. Am.), Geol. of North Am. Ser., L: 185-210.

1995. The Danish Lithosphere Centre: a new earth science centre in Denmark. Rapp. - Groenl. Geol. Unders., 165:98-99.

Larsen, H.C., Brooks, C.K., Hopper, J.R., Dahl-Jensen, T., Pedersen, A.K., Nielsen, T.D.F., and Field Parties, 1995. The Tertiary opening of the North Atlantic: DLC investigations along the east coast of Greenland. Rapp.-Groenl. Geol. Unders., 165:106-115.

Larsen, H.C., Dahl-Jensen, T., and Hopper, J.R., in press. Crustal structure along the Leg 152 drilling transect. In Saunders, A.D., Larsen, H.C., Clift, P.D., and Wise, S.W., Jr. (Eds.), Proc. ODP, Sci. Results, 152: College Station, TX (Ocean Drilling Program).

Larsen, H.C., and Jakobsdóttir, S., 1988. Distribution, crustal properties and significance of seaward-dipping sub-basement reflectors off East Greenland. In Morton, A.C., and Parson, L.M. (Eds.), Early Tertiary Volcanism and the Opening of the Northeast Atlantic: Geol. Soc. Spec. Publ. London, 39:95-114. 
Larsen, H.C., Saunders, A.D., Clift, P.D., et al., 1994. Proc. ODP, Init. Repts., 152: College Station, TX (Ocean Drilling Program).

Larsen, H.C., Saunders, A.D., Larsen, L.M., Lykke-Andersen, H., Leg 152 Scientific Party, Marcussen, C., and Clausen, L., 1994. ODP activities on the South-East Greenland margin: Leg 152 drilling and continued site surveying. Rapp.-Groenl. Geol. Unders., 160:75-81.

Larsen, H.C., Sawyer, D.S., and the NARM-DPG, 1991. North Atlantic rifted margins detailed planning group report. JOIDES J., 3:24-26.

Larsen, L.M., Watt, W.S., and Watt, M., 1989. Geology and petrology of the Lower Tertiary plateau basalts of the Scoresby Sund region, East Greenland. Bull.-Groenl. Geol. Unders., 157:1-164.

Mutter, J.C., Buck, W.R., and Zehnder, C.M., 1988. Convective partial melting, 1. A model for the formation of thick basaltic sequences during the initiation of spreading. J. Geophys. Res., 93:1031-1048.

Mutter, J.C., Talwani, M., and Stoffa, P.L., 1982. Origin of seaward-dipping reflectors in oceanic crust off the Norwegian margin by "subaerial seafloor spreading." Geology, 10:353-357.

Myers, J.S., 1980. Structure of the coastal dyke swarm and associated plutonic intrusions of East Greenland. Earth Planet. Sci. Lett., 46:407-418.

Myers, J.S., Gill, R.C.O., Rex, D.C., and Charnley, N.R., 1993. The Kap Gustav Holm Tertiary Plutonic Centre, East Greenland. J. Geol. Soc. London, 150:259-276.

Nielsen, T.F.D., Soper, N.J., Brooks, C.K., Faller, A.M., Higgins, A.C., and Matthews, D.W., 1981. The pre-basaltic sediments and the lower basalts at Kangerdlugssuaq, East Greenland: their stratigraphy, lithology, paleomagnetism and petrology. Medd. Groenl., Geosci., 6:1-25.

Pálmason, G., 1986. Model of crustal formation in Iceland, and application to submarine mid-ocean ridges. In Vogt, P.R., and Tucholke, B.E. (Eds.), The Western North Atlantic Region: Boulder, CO (Geol. Soc. Am.), Geol. of North Am. Ser., M:87-98.

Richards, M.A., Duncan, R.A., and Courtillot, V.E., 1989. Flood basalts and hot-spot tracks: plume heads and tails. Science, 246:103-107.
Roberts, D.G., Schnitker, D., et al., 1984. Init. Repts. DSDP, 81: Washington (U.S. Govt. Printing Office).

Schilling, J.-G., 1986. Geochemical and isotopic variation along the MidAtlantic Ridge axis from $79^{\circ} \mathrm{N}$ to $0^{\circ} \mathrm{N}$. In Vogt, P.R., and Tucholke, B.E. (Eds.), The Western North Atlantic Region: Boulder, CO (Geol. Soc. Am.), Geol. of North Am. Ser., M:137-156.

Sinton, C.W., Larsen, H.C., and Duncan, R.A., 1994. The timing of the volcanism at the southeast Greenland Margin, ODP Leg 152. Eos, 75:607.

Srivastava, S.P., and Tapscott, C.R., 1986. Plate kinematics of the North Atlantic. In Vogt, P.R., and Tucholke, B.E. (Eds.), The Western North Atlantic Region: Boulder, CO (Geol. Soc. Am.), Geol. North Am. Ser., M:379-404.

Talwani, M., and Eldholm, O., 1977. Evolution of the Norwegian-Greenland Sea. Geol. Soc. Am. Bull., 88:969-999.

Thirlwall, M.F., 1995. Generation of Pb isotopic characteristics of the Iceland plume. J. Geol. Soc. London, 152:991-996.

Thirlwall, M.F., Upton, B.G.J., and Jenkins, C., 1994. Interaction between continental lithosphere and the Iceland plume: $\mathrm{Sr}-\mathrm{Nd}-\mathrm{Pb}$ isotope geochemistry of Tertiary basalts, NE Greenland. J. Petrol., 35:839-879.

Viereck, L.G., Taylor, P.N., Parson, L.M., Morton, A.C., Hertogen, J., Gibson, I.L., and the ODP Leg 104 Scientific Party, 1988. Origin of the Palaeogene Vøring Plateau volcanic sequence. In Morton, A.C., and Parson, L.M. (Eds.), Early Tertiary Volcanism and the Opening of the Northeast Atlantic. Geol. Soc. Spec. Publ. London, 39:69-83.

White, R., and McKenzie, D., 1989. Magmatism at rift zones: the generation of volcanic continental margins and flood basalts. J. Geophys. Res., 94:7685-7729.

\section{Ms 163IR-101}
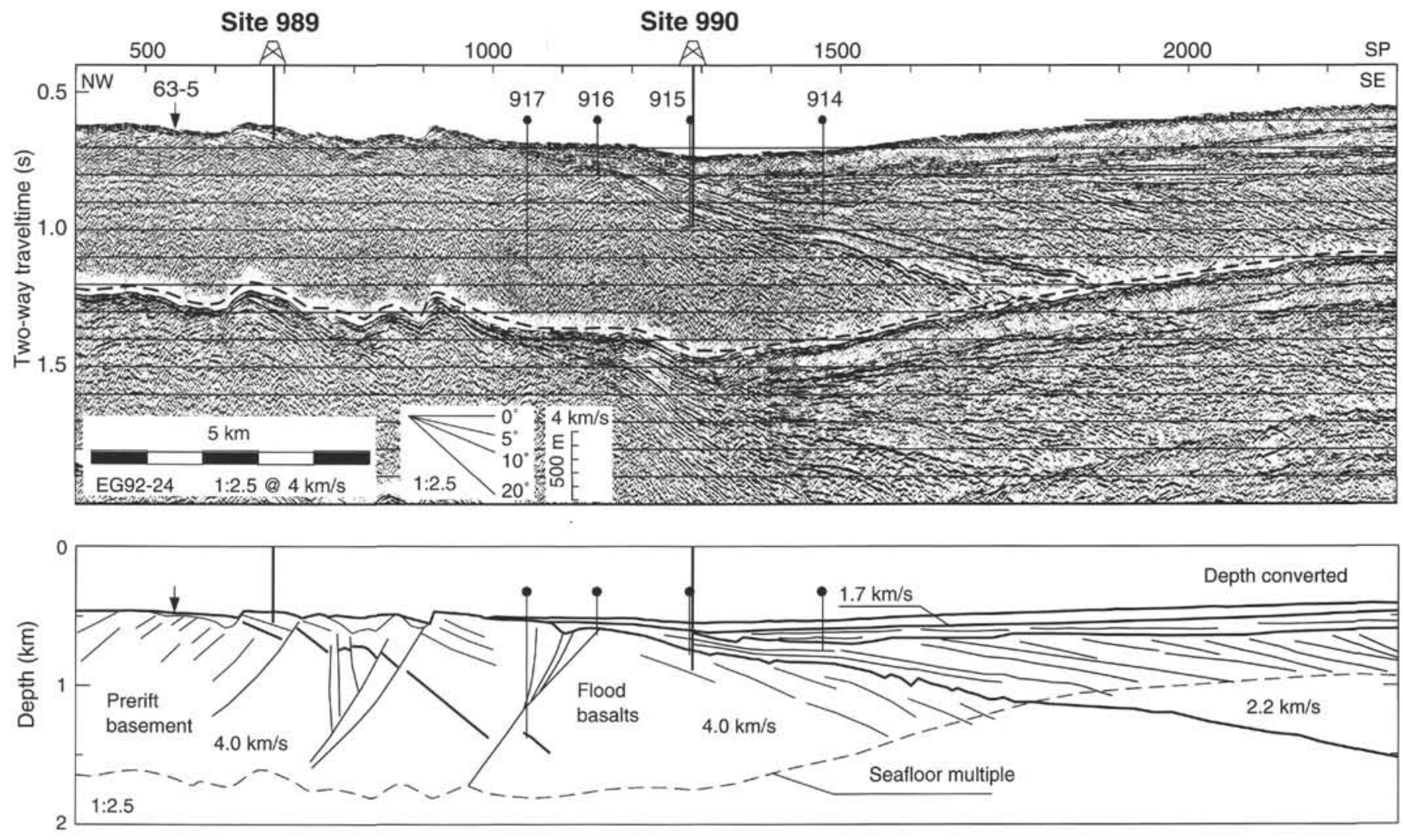

Figure 7. Seismic Line EG92-24 and interpretation along the inner EG63 transect. 

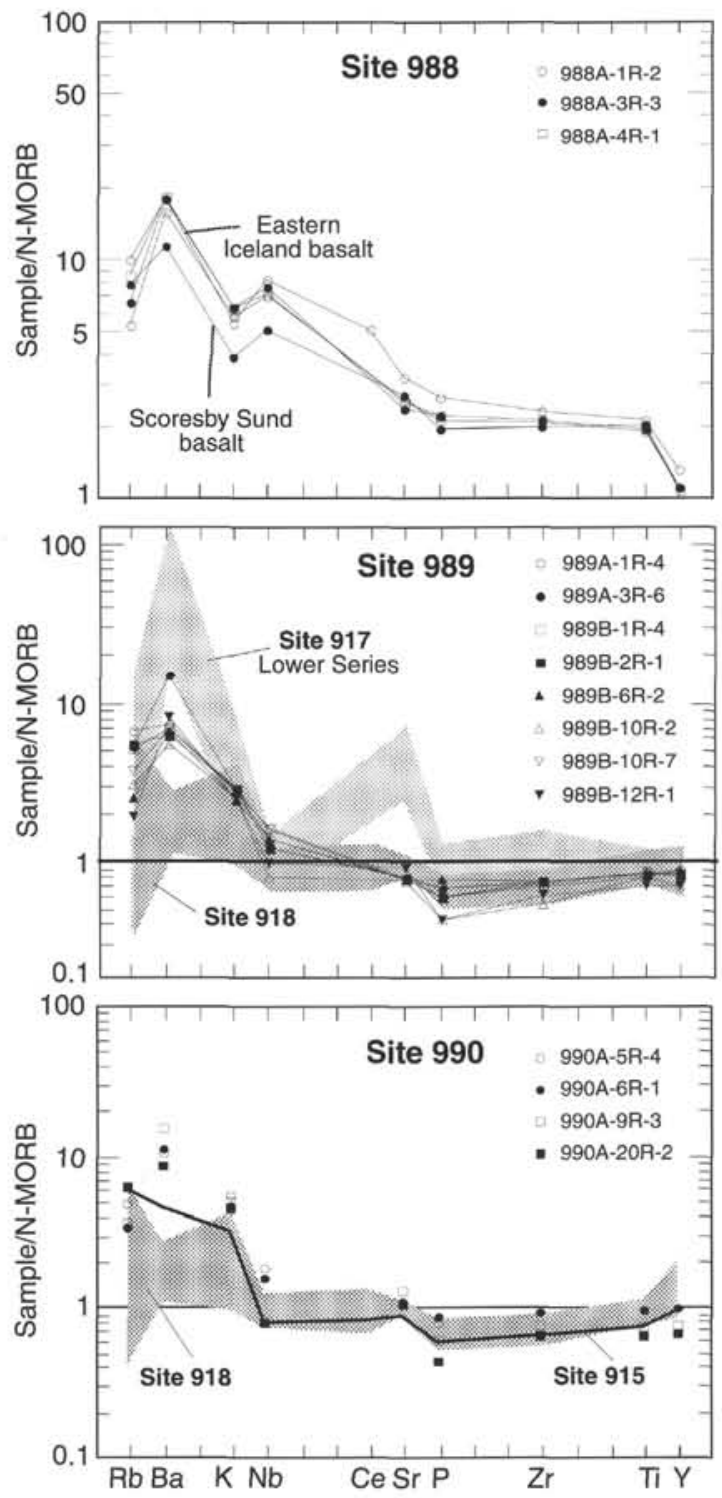

Figure 8. Normalized minor element and trace-element patterns of the SDRS along the EG63 (Sites 915, 917, 918, 989, and 990) and EG66 transects (Site 988). Note the different vertical scale for the Site 988 plot. 